\title{
アルミニウム皮びその合金の眞空放電脫ガス法に關する政究（第2 報)
}

\section{種ßの脫ガス處理を施せる $\mathrm{Al}$ の格子常數變化精密測定についで}

\section{岩村震郎** $千$ 早 正** 鉿末 正敏**}

Harerô Iwamura, Tadashi Chihaya and Masatoshi Suzuki : Studies on the Degassification of Al and Its Alloys by the Spark Method in Vacuo (2nd report) On the Effect of Gases to the Lattice Constant of Aluminium: In this report, the authors examined the changes of lattice constant of $99.7 \% \mathrm{Al}$, which was treated with various degassification methods. In general, the degassed specimens showed the contraction of lattice. Among the various methods under the atmospheric pressures, namely, remelting, flux treatment and the chlorine gas treatment, the last offered the best results.

By the vacuum melting method, superior to any other methods mentioned above, it is believed that every and all gases can be extracted, but by the spark method in vacuo, we obtained more contraction of lattice constant and more quantities of extracted gases, especially, when the specimens are used as the plus electrode, say, the electron bombardments are given, we obtained the best results.

(Received May 6, 1950)

\section{I. 緒旁}

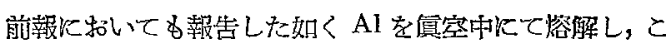

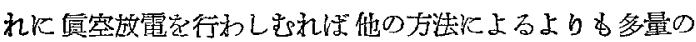
ガスが放出されることを誃め得るが，他面富驗條件の複雜な

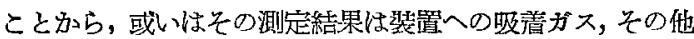

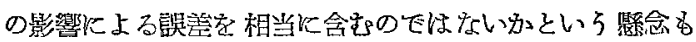
起らめでもないかと思われる。本報见おいてはとの点起磪 めるため, 促來有效とされている種及の処理法学行つた試料

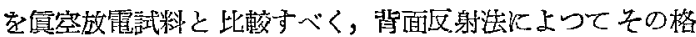

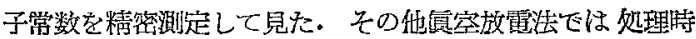
間を变化した場合の状沉をむ觀察した。

\section{II. 試料作製法}

便用地金は $99.7 \%$ の刻印安るるので製造所不明, ${ }^{\circ}$ 䀡和

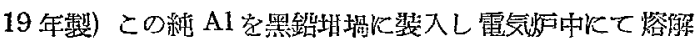
した。試料を区分すると，

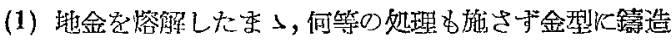

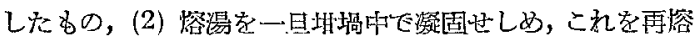
融して $720^{\circ}$ 程度の比校的低い温度上り鑄边九でもの，(3)

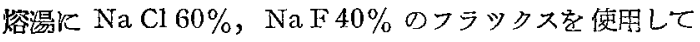

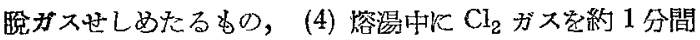
吹き込んを脫ガスせしめたるの。

以上のbのに付しそれぞれ 处理前に烙晹守に水蒸気索大

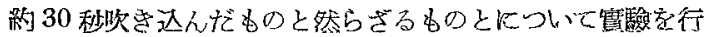
つたわけた岁る。

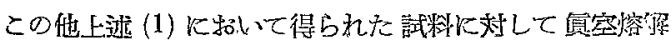
区び盾空放電揢解を行つたすのを試料とした。更炕水蒸気

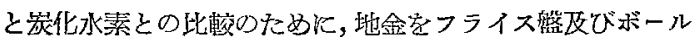

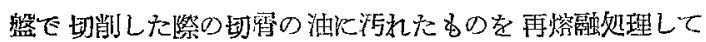
同時澥驗を行って見た。

\section{III. 蒀 驗 㢣}

䇺驗の装置としては前焃に示したものと同一のものを用

\footnotetext{
** 茨城大学工学部

* 昭和 24 年 11 月本会名古屋大会に登㔛
}

いたが，今回は特に放電以よる眖分スは如何なる作用に基ず

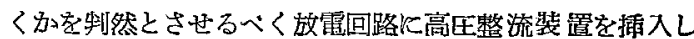
て直流炕よる放電を行つてみた。

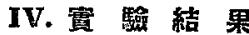

(1) 格子常數の戀化について

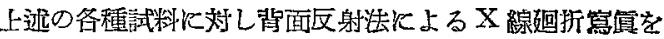

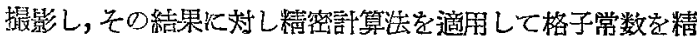
㤎测定した結果は Table 1 の如くなつた・こはに比較をと

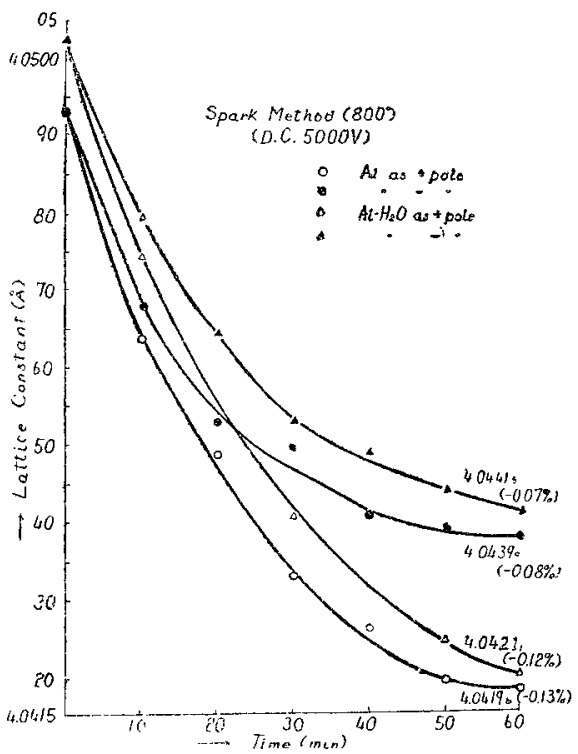

Fig. 1 The Experimental Results of Spark Method for Pure Aluminium,

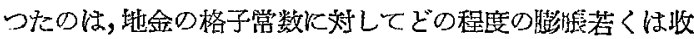
縮を來しているが示しているものたあるな物盾空放電 处理索行つたるのは試料の極性を交換し，又処理時間安 10

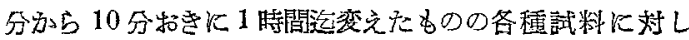


Table 1 The Lattice Constant Changes of Aluminum after Various Degassification Treatments.

\begin{tabular}{|c|c|c|c|c|}
\hline Treatment & Specimens & Lattice Constant & Comparison & Remarks \\
\hline & Al ingot & $4.0470_{5}$ & & $99.7 \% \mathrm{Al}$ \\
\hline \multirow{2}{*}{ As cast } & $\mathrm{Al}$ & $4.0493_{0}$ & +0.056 & \multirow{2}{*}{$\begin{array}{l}800^{\circ} \text { Cast } \\
\text { with no flux }\end{array}$} \\
\hline & Al- $\mathrm{H}_{2}$ Osàturate & $4.0502_{5}$ & +0.079 & \\
\hline \multirow{4}{*}{ Remelting } & $\mathrm{Al}$ & $4.0461_{7}$ & -0.022 & \multirow{4}{*}{$\begin{array}{l}720^{\circ} \\
\text { Cast }\end{array}$} \\
\hline & $\mathrm{Al}-\mathrm{H}_{2} \mathrm{O}$ sat. & $4.0465_{2}$ & -0.013 & \\
\hline & Scrap No. 1 & $4.0461_{9}$ & -0.021 & \\
\hline & Scrap No. 2 & $4.0456_{3}$ & -0.035 & \\
\hline \multirow{2}{*}{ Flux treatment } & $\mathrm{Al}$ & $4.0437_{6}$ & -0.082 & $750^{\circ}$ Cast \\
\hline & $\overline{\prime \prime}$ & $4.0465_{3}$ & -0.013 & $800^{\circ}$ Cast \\
\hline \multirow{2}{*}{$\left(\begin{array}{ll}\mathrm{NaCl} & 60 \% \\
\mathrm{NaF} & 40 \%\end{array}\right)$} & $\mathrm{Al}-\mathrm{H}_{2} \mathrm{O}$ sat. & $4.0447_{5}$ & -0.057 & $750^{\circ}$ Cast \\
\hline & $"$ & $4.0471_{4}$ & +0.002 & $800^{\circ}$ Cast \\
\hline $\mathrm{Cl}_{2}$ gas treatment & $\mathrm{Al}$ & $4.0450_{1}$ & -0.050 & \multirow{2}{*}{$800^{\circ}$ Cast } \\
\hline$(1 \mathrm{~min})$ & $\mathrm{Al}-\mathrm{H}_{2} \mathrm{O}$ sat. & $4.0464_{2}$ & -0.015 & \\
\hline \multirow{2}{*}{$\begin{array}{l}\text { Vacuum melting } \\
\qquad(60 \mathrm{~min})\end{array}$} & $\mathrm{Al}$ & $4.0433_{0}$ & -0.093 & \multirow{2}{*}{$800^{\circ}$} \\
\hline & $\mathrm{A} 1-\mathrm{H}_{2} \mathrm{O}$ sat. & $4.0442_{9}$ & -0.067 & \\
\hline \multirow{4}{*}{$\begin{array}{l}\text { Spark method } \\
\text { Melting }\end{array}$} & $\mathrm{Al}$ & $4.0419_{6}$ & -0.126 & \multirow{2}{*}{$\begin{array}{l}800^{\circ} \\
\text { Samples are } \\
\text { +pole }\end{array}$} \\
\hline & $\mathrm{Al}-\mathrm{H}_{2} \mathrm{O}$ sat. & $4.0421_{1}$ & -0.122 & \\
\hline & $\mathrm{Al}$ & $4.0439_{9}$ & -0.076 & \multirow{2}{*}{$\begin{array}{l}800^{\circ} \\
- \text { pole }\end{array}$} \\
\hline & $\mathrm{Al}-\mathrm{H}_{2} \mathrm{O}$ sat. & $4.0441_{5}$ & -0.072 & \\
\hline
\end{tabular}

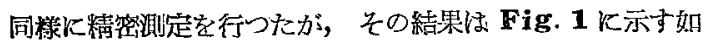
くになつた.

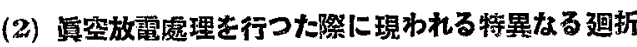 圖形について}

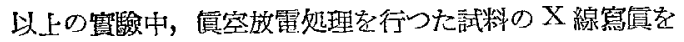
撮影して見ると、との撮影方向に上つて特異な迴折図形を示 すものがあるととを発見した。

この点汇ついては現在末梡全K泊究し盡してはいない

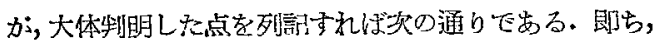

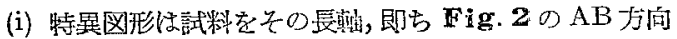

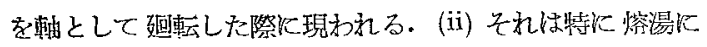

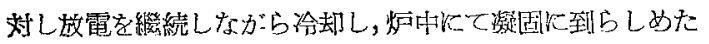

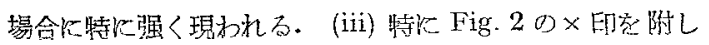

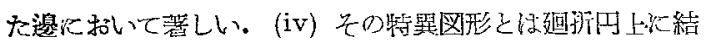
昆粒子の方向性を示昌と，思われる集䅡点を生ずるのである

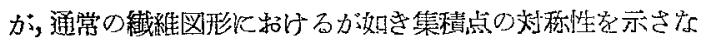
い（v）現在の所はつきりと断言は出來ないが，集稍点の

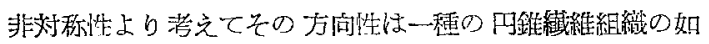

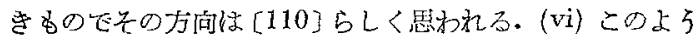
な組織の出るのは勿諭炉中で凝固せしぬた場合が著しいの てあるが，午の場合美面層は相当大き結昆粒の存在を示

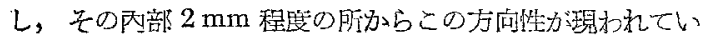

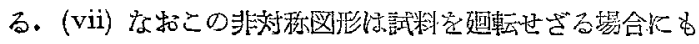

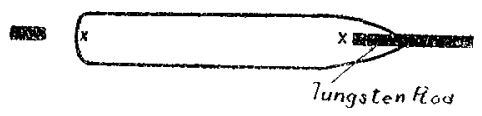

Fig. 2 The Mark " $\mathrm{X}$ " shows the Points that has Especially strong Singular Diffraction Patterns.

適当な撮影方向をとれば現われてくる。（viii）試料の極性 を交換して見ても，この特異図形には殆えど夜化を生ずるこ とはない。

\section{V. 結果の洘察}

計算の結果, 地金の格子常数挝通常考文られている值上り

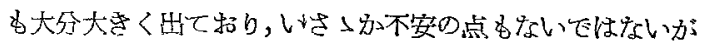
その他の許算值もすべて同一玳金を使用し、同一のカメラを 撮影したものの結果であるから、少くとも定性的には正しい 結果が出ていると信ずる。

さて Table 1を見ふと，フラックス等を一切使用壮す⿺，

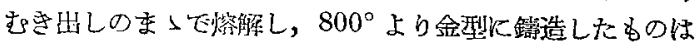

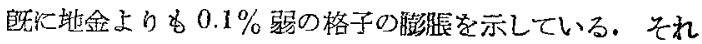

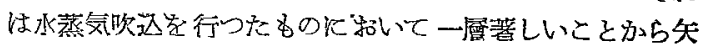
張り四收がスの影䇾によるものと思称れる。

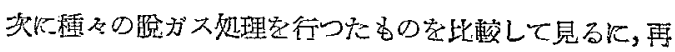

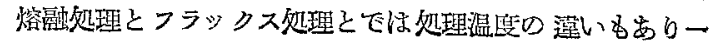




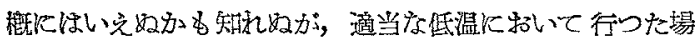
合,フラックスを使朋した場合の方が良好な結果定示すの と思われる。この琵合フラックスとして用いたものは Na

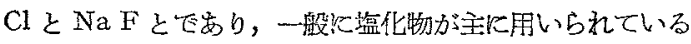

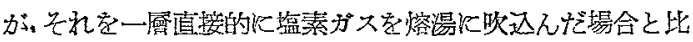
賋して是ると，Table 1 からも制る如と塩素がスを用いた

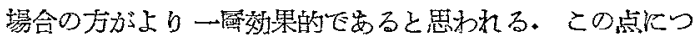
いては高榅越二氏(1) 篮素がス使用が可成有效であるとと を既炕報告されている。

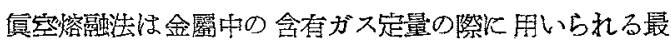

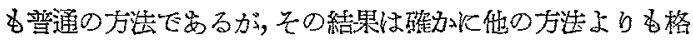

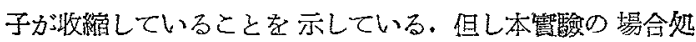
理特間か漂いということはあるが，現に顀室放電法によれば

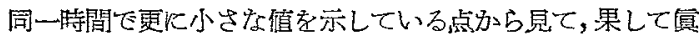

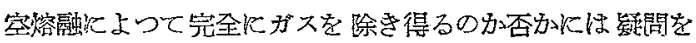
持たざるを得ないのていかるまいか子思われる。

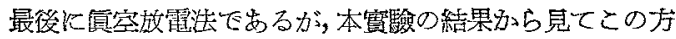

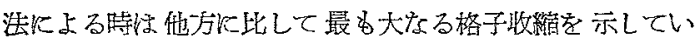

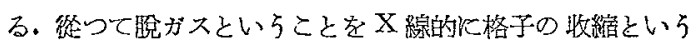

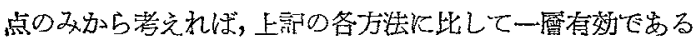
と荐えられる。

而して故電がそれては一体如同なる炏果を有しているの

(1) 高橋, 本誌, 5 (1941), 465 .
かといら点関しては Fig.1 よりるかかる如く、試料を十程

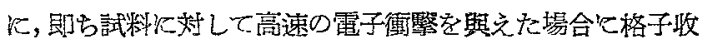
紛首か著しい点より，その作用が相当な部分を占めているすの

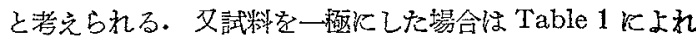
ば単に盾空撘解を行つた場合と大善ない值が示されている。

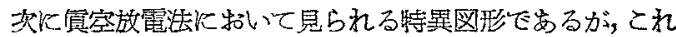

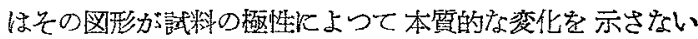

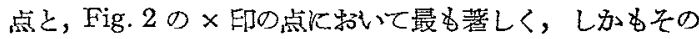
邊から発散した方茼檕有していると考えられる点から推

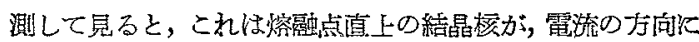

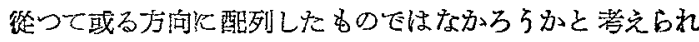
る.

\section{VI. 總栝}

(1) $99.7 \%$ の純 Al K対し種々の䐋ガス処理を行つて見

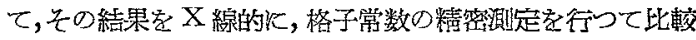
検討した。 (2) 䐋がス浩としては, 結晶格子の收縮という点

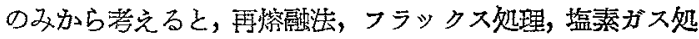

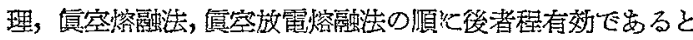

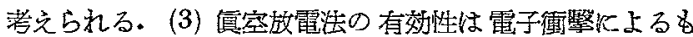

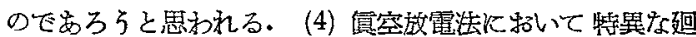
折図形を得ることがあるが, その本体については未汒完全に

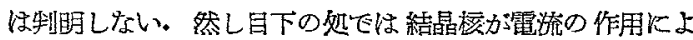
つて，その方向炕結晶の一定方南（(110)かと思われる) 配 列したのたまろろと考える。 